V. Tsekhanovych

UDC 330.341.1:332.1+339.92

doi: 10.12958/1817-3772-2019-4(58)-95-99

\author{
V. Tsekhanovych, \\ Postgraduate Student, \\ ORCID 0000-0001-7199-8558, \\ Department of Economic Theory, \\ Marketing and Entrepreneurship State University \\ Luhansk Taras Shevchenko National University
}

\title{
MODELS OF INNOVATION INFRASTRUCTURE IN EUROREGIONS
}

Formulation of the problem. Currently, for Ukraine, the activation of Euroregional cooperation is an extremely important component of economic development, since many regions of our country directly border the EU, forming Euroregions. Of particular importance is the activation of the innovation component in the economy of the border territories, which is manifested in the development of innovation infrastructure, cooperation of scientific institutions, joint research and projects, participation of the regions of Ukraine in European programs for the development and implementation of innovations.

Innovative development of Euroregions necessitates contacts and interaction between innovative entities through the development of infrastructure support. Understanding the limitations of traditional factors of economic development makes researchers pay more attention to innovative processes in Euroregions that can ensure the formation of long-term competitive advantages of economic growth. Under such conditions, a balanced policy of creating and supporting innovative infrastructure objects can become the most significant lever for activating innovative processes in Ukraine.

Analysis of the last publications. Exploring the organizational and economic aspects of integration of Euroregions, domestic scientists O. Honta (2000) and I. Storonianska (2002) advocate sectoral approaches to Euro-regional cooperation. S. Hlukhova (2010) believes that it is necessary to differentiate the factors of influence on the innovation activity of the region from the position of the origin of the regional aspects of innovative development in the economic system of the regions, the problems of determining and analyzing factors that hinder and promote innovation, a number of scientific papers of the following authors are devoted: P. Musiienko, and A. Brazhnykova (2007), L. Semiv (ed.) (2009), V. Gubina (2010), A. Bezuska and V. Lukianykhin (2010), V. Uzunov (2012), E. Zelinskaya (2013), N. Pavlikha and Yu. Marchuk (2013), V. Miklovda (ed.) et al. (2013), S. Kovalenko (2014), H. Zavadskykh (2014), V. Pak (2016), V. Kravtsiv (ed.) (2016). However, the development of certain problematic issues in the Euroregion calls for a deeper study of national business cultures and profiles of managers from different countries, but there are few examples of such development. V. Chebotarev's (2019) works are devoted to this problematics. Exploring the works of foreign scientists such as R. Dragneva and K. Wolczuk (2014) from the UK, M. Krasucka (2010) from Poland and M. Moraliyska (2015) from Bulgaria, it can be argued that on the basis of these works, today there is a formation of a scientific direction that studies the transformation of socio-economic forms and types of entrepreneurship, new ways of managing these processes, and since the methodological basis in this direction is in the process of formation, this causes the need for deep scientific development of this issue.

Research objectives. In the study of innovative models in Euro-regions was reviewed by the infrastructure innovation investment model and clustering of European regions, and on the basis of theoretical and methodological research innovation infrastructure as a factor of innovative development of practical recommendations on the functioning of the innovation infrastructure in the regions. The article defines the concepts of innovative opportunities in Euro-Regional activities. Conclusions are drawn and further development prospects are defined.

Presentation of the main research material. The innovation system of the state can be considered as a set of its regional components - regional innovation systems. Based on this, we can highlight some topical issues.

1. The national innovation system as a whole should have a unified legislative framework and budget policy, and the flexibility of this system is necessary for timely adaptation to dynamic internal and external conditions, which should be provided by decentralizing management, organizing many centers of analysis and response. With regard to Ukraine, taking into account the system of political and administrative structure, levers for managing regional development should be created, and the classification of innovations is proposed to additionally introduce a group of innovations at the regional level (that is, innovations that exist in the country, but are new to the region).

2. Innovation potential is a component of the region's socio-economic potential. The innovation potential of a region can be defined as a set of scientific, technical, material, financial, human, institutional, and other resources of the region that can be used for innovation. It contains elements such as technological progress, institutional forms associated with the mechanisms of scientific and technological development, as well as the in- 
novative culture of society, its susceptibility to innovation. For a comprehensive description of the state of innovative development of regions, together with the concept of "innovative potential", we suggest using a broader concept - "innovative opportunities". Under the innovative potential of the region is necessary to understand the totality of the assessment of the needs of the region in innovation upgrading (primarily the production and technological sphere), its innovative potential as well as existing organizational-legal, financial-economic, institutional, technological and other conditions for deployment of innovation.

The state of innovation infrastructure development directly affects the development of Euro-regional cooperation in the innovation sphere. Regional innovation infrastructure is a set of special innovation institutions and networks that are interconnected and ensure the development and support of all stages of the innovation process in the region in order to increase its innovative potential [16].

The main elements of the development of regional innovation infrastructure, which indicate the possibility of forming competitive advantages of the region and contribute to the development of its innovative potential, include: technoparks, scientific parks, innovation and technology centers, business incubators, venture firms, consulting and analytical firms, technopolises, etc.

If we consider these infrastructures, we can say that technoparks can be considered as an innovative and investment model of Euro-regional cooperation. Today, there are 7 technoparks in Ukraine that take part in Euroregional activities. Among them, we can highlight the Yavoriv Technopark - the bug and Carpathian Euroregions, and Eco Ukraine. The cluster approach contributes to the effective implementation of the innovation and investment economic model of Euro-regional cooperation. The experience of foreign countries shows that the emergence of clusters based on regional specialization increases the competitiveness of national economies. Clustering processes should be regulated by the legal documents of the countries participating in crossborder cooperation.

The basis of clustering within Euroregions is the creation of scientific, technical and logistics clusters. A scientific and technical cluster is an organizational structure that includes research institutes, higher education institutions, and enterprises where scientific and technical developments will be implemented. The implementation of the scientific and technical cluster in the Euroregions will solve the issue of updating the material and technical base of scientific institutions and higher education institutions, increase the share of innovative and active enterprises, increase the science intensity of GDP, create new jobs and improve the export potential of States. Scientific and technical clusters can be developed on the basis of existing technoparks.
Here, the Euro-regional cluster uses innovations as a technology to achieve the region's competitive advantages and a strategy for future development. These advantages include the possibility of promoting innovative clustering in Euroregions by financing and participating in cross-border and Euro-regional cooperation programs and projects.

Considering the prerequisites for the formation of Euro-regional cluster formations, it is necessary to analyze the Euroregions as a single territory, which should correspond to the equivalent selection of potential participants in such a cluster.

Thus, in order to determine the areas of functioning of a Euro-regional cluster formation, it is necessary to determine the competitive advantages and specialization of the border territories that are part of the corresponding Euro-regional space

As for Euro-regional business incubators, this activity is currently in its infancy. According to statistics, there are 76 business incubators in Ukraine. In fact, there are no more than 10 effective ones, and there are no Euro-regional ones at all. Today, a business incubator is known in Rezina (Moldova, Euroregion " Dniester») [4].

In Ukraine, business incubators as a direction of small business support are characterized by an evolutionarily determined specificity. There are problems both in the theoretical and methodological support, and in the implementation of the business incubation concept in practice. This is, first of all, the absence of a single conceptual and categorical apparatus, the failure to resolve issues of organizing financing and lending to business incubators, and the involvement of highly qualified personnel.

As part of the development of state policy at the national level, it is also advisable to develop a state program for the sustainable development of Euroregions and determine the main priorities for their development. In particular, the development of the border regions of Ukraine will significantly improve the activities of the Euro-regional formation by increasing the competitiveness of the territories belonging to its composition. It is necessary to consider that we should support the traditional sector and industry inherent in areas that are members of Euroregions, as well as save and that we should use innovative mechanisms to stimulate the development of the Ukrainian territories, which, compared to other members of Euroregional formation may lag in their development [9].

To this end, it is important to encourage cooperation between scientific and technological centers and small and medium-sized enterprises located on the territory of Ukraine and neighboring countries. It is also necessary to make a separate emphasis on increasing the accessibility of certain territories located on the periphery, developing infrastructure facilities, transport and com- 
munication, and thus contributing to improving the provision of social services to the population.

Conclusions. Defining the creation of specialized infrastructures as a tool for activating the development of entrepreneurship in various fields of activity, we believe that the main motivation for creating such a structure is to increase the self-sufficiency of the economies of border territories, create the basic foundations for the development of new enterprises, stimulate job creation, develop cross-border infrastructure to support small businesses, and increase the welfare of the population of border territories through the development of entrepreneurship.

Successful implementation of the innovation and investment model of Euroregions depends on sufficient funding for projects and programs. Given the crisis state of the national economy, the financial assistance of the European Union plays a significant role in Euroregional cooperation.

Based on the above, the following development prospects can be identified:

1. One of the ways to improve the socio-economic development of Ukraine is to activate cross-border cooperation by creating Euroregions, which are an organizational form of cooperation between administrative and territorial units of European States, carried out in accordance with bilateral or multilateral agreements on cross - border cooperation.

2. To enhance cross-border cooperation through the implementation euroregionalmap structures it is necessary to use the innovative-investment model of development, which as a result of General economic modernization and growth in the share of high-tech industries will contribute to improving the socio-economic situation of border areas.

3. An important factor of adoption of innovation investment model of Euroregional collaboration is the creation of scientific-technological structures technological Park type, which unite scientific organizations, design bureaus, educational institutions, industrial enterprises and promote the introduction into production of scientific and technical developments.

4. Effective implementation of the innovation and investment model of Euro-regional cooperation involves the use of a cluster approach. The basis of clustering within Euroregions is the creation of scientific, technical and logistics clusters.

5. The implementation of Euro-regional structures in practice depends on the reliability of funding. At present, the most effective source remains the EU's financial assistance.

\section{Literature}

1. Гонта О.I. Організаційно-економічні аспекти інтеграції прикордонних регіонів: дис. канд. екон. наук: 08.10.01/ Чернігівський державний технологічний університет. Чернігів, 2000. 214 с. 2. Сторо- нянська I.3. Організаційно-економічні основи міжрегіонального співробітництва прикордонного регіону (на прикладі Західного регіону України): дис. канд. екон. наук: 08.10.01/ НАН України; Інститут регоінальніх досліджень. Львів, 2002. 220 с. 3. Глухова С. В. Методичний підхід щодо оцінки результативності інноваційної діяльності будівельних підприємств. Ефективна економіка. 2010. №10. URL: http: //www.economy.nayka.com.ua/?op=1\&z=352. 4. Губина В.С. Государственное регулирование регионального развития: европейский опыт. URL: https://cyberleninka. ru/article/n/gosudarstvennoe-regulirovanie-regionalnogorazvitiya-evropeyskiy-opyt. 5. Зелинская Е.3. Региональные трансграничные кластеры как формы современных систем управления в реальном секторе экономик. Псковский регионологический журнал. 2013. №16. С. 16-18. 6. Павлов В. І., Корецький Ю. М. Інноваційний потенціал регіону: діагностика та реалізація. Луцьк: Надстир'я, 2004. 244 с. 7. Павліха Н. В. Роль інноваційної інфраструктури міст-метрополій в забезпеченні розвитку регіонів. Соціально-економічні проблеми сучасного періоду України. Метрополійні функиії обласних иентрів Західного регіону: зб. наук. праць / НАН України. Ін-т регіональних досліджень; рекол.: В. С. Кравців (відп. ред.). Львів, 2013. Вип. 2 (100). (С. 216-224). 8. Папп В.В. Стратегічні напрямки розвитку регіональних інноваційних процесів. URL: http: //experts.in.ua/baza/analitic/index.php?ELEMENT $\mathrm{ID}=34700$. 9. Кифяк В.Ф. Транскордонний бізнес-інкубатор як один із інструментів активізації розвитку підприємництва в сфері рекреації та туризму. Вісник Чернівецького торговельно-економічного інституту. 2011. Вип. I (41). 10. Коваленко С. Концепція транскордонної кластерної системи в контексті технологічного укладу. ВісникТНЕУ. 2014. № 3. С. 100-112. 11. Мусієнко П. В., Бражникова А. Г. Технопарк як організаційна форма розвитку інноваційного потенціалу в Україні. Держава та регіони. Серія: Економіка та підприємництво. 2007. № 3. С. 154-157. 12. Томарева В.В. Диспропорції соціально-економічного розвитку регіонів України та шляхи їх зниження. URL: http://archive.nbuv.gov.ua/portal/soc_gum/Dtr_ep/2010

6/files/EC610_23.pdf. 13. Узунов В. В. Розвиток інноваційної інфраструктури регіонів України. Державне управління: удосконалення та розвиток. 2012. №8. URL: http://www.dy.nayka.com.ua/?op=1\&z=638. 14. Семів Л.К. Інтелектуально-інноваційний розвиток регіону в контексті євроінтеграції / за. ред. Л.К. Семів. Львів: Інститут регіональних досліджень НАН України, 2009. 483 с. 15. Пак В. І. Підвищення ефективності співробітництва в межах Карпатського єврорегіону у сфері міждержавного регіонального управління. Ефективність державного управління. 2016. Вип. 3. С. 167-173. URL: http://nbuv.gov.ua/UJRN/ efdu_2016_3_20. 16. Безуська А. Ю., Лук'янихін В.О. Визначення сутності регіонального управління, його основних процесів і державних пріоритетів розвитку. URL: essuir.sumdu.edu.ua/bitstream/.../7827/1/1.doc. 17. Чеботарьов В. А., Глінковська-Краузе Б., Чеботарьов С. В. Менеджмент персоналу економічних 
підрозділів підприємств: обгрунтування вихідних інноваційних засад забезпечення. Економічний вісник Донбасу. 2019. № 3(57). С. 156-161. doi: 10.12958/18173772-2019-3(57)-156-161. 18. Розвиток транскордонного співробітництва: науково-аналітична доповідь / НАН України, ДУ «Інститут регіональних досліджень імені М. І. Долішнього НАН України»; Редактор В.С. Кравців. Львів, 2016. 125 с. (Серія «Проблеми регіонального розвитку»). 19. Dragneva R., Wolczuk K. The EU-Ukraine Association Agreement and the Challenges of Inter-Regionalism. Review of Central and East European Law. 2014. Vol. 39. P. 213-244. doi: 10.1163/1573035200000019. 20. Maja Krasucka. Rola euroregionów we współpracy transgranicznej na przykładzie Euroregionu. Pradziad Ekonomiczne Problemy Ustug. 2010. № 61. P. 199-210. 21. Monika Moraliyska. Regional Economic Cooperation in the Western Balkans and Its Impact on Bulgaria. Economic Alternatives. 2015. Issue 1. P. 100-117. 22. Стратегічні пріоритети економічного розвитку регіону: монографія / За ред. В.П. Мікловди, С.С. Слави, С.В. Сембера, В.В. Папп. Ужгород: Видавництво ФОП Бреза А.Е. 2013. 548 с. 23. Завадських Г.М. Диспропорції соціально-економічного розвитку регіонів України та шляхи їх зниження. Збірник наукових праць Таврійського державного агротехнологічного університету (економічні науки). 2014. №2(26). C. 76-79.

\section{References}

1. Honta, O. I. (2000). Organizational and economic aspects of border regions integration. Abstract of Ph.D. dissertation, Placement of the productive forces and regional economy. Chernihiv, Chernihiv State Technological University [in Ukrainian].

2. Storonianska, I. Z. (2002). Organizational and economic foundations of interregional cooperation in the border region (case study of the Western region of Ukraine). Doctor's thesis. Lviv, Institute for Regional Studies of NAS of Ukraine [in Ukrainian].

3. Hlukhova, S. V. (2010). Technique of the estimation productivity innovation activity the building enterprises. Efektyvna ekonomika, no. 10. Retrieved from http://www.economy.nayka.com.ua/?op=1\&z=352 [in Ukrainian].

4. Gubina, V. S. (2010). State regulation of regional development: European experience. Upravlenie ekonomikoi: teoriya $i$ praktika, pp. 153-162. Retrieved from https://cyberleninka.ru/article/n/gosudarstvennoe-reguliro vanie-regionalnogo-razvitiya-evropeyskiy-opyt [in Russian].

5. Zelinskaya, E. Z. (2013). Regional cross-border clusters as forms of modern management systems in the real sector of the economy. Pskovskii regionologicheskii zhurnal, no. 16, pp. 12-18 [in Russian].

6. Pavlov, V. I. and Koretskyi, Yu. M. (2004). Innovatsiinyi potentsial rehionu: diahnostyka ta realizatsiia [Innovative potential of the region: diagnosis and implementation]. Lutsk, Nadstyr'ia. 244 p. [in Ukrainian].

7. Pavlikha, N. V. and Marchuk, Yu. V. (2013). Role of innovative metropolitan infrastructure in regional deve- lopment. Sotsialno-ekonomichni problemy suchasnoho periodu Ukrainy, vol. 2, pp. 216-224 [in Ukrainian].

8. Papp V.V. Stratehichni napriamky rozvytku rehionalnykh innovatsiinykh protsesiv [Strategic directions of development of regional innovation processes]. (n.d.). Retrieved from http: //experts.in.ua/baza/analitic/ index.php?ELEMENT_ID=34700 [in Ukrainian].

9. Kyfiak, V. F. (2011). Cross-border business incubator as one of the tools for stimulating the development of entrepreneurship in the sphere of recreation and tourism. Bulletin of Chernivtsi Institute of Trade and Economics. Economic Sciences, vol. 1, pp. 229-235 [in Ukrainian].

10. Kovalenko, S. (2014). The concept of cross-border cluster systems in the context of technological development. The Herald of Ternopil National Economic University, vol. 3, pp. 110-112 [in Ukrainian].

11. Musiienko, P. V. and Brazhnykova, A. H. (2007). Technopark as an organizational form of innovation potential development in Ukraine. State and Regions. Series: Economics and Entrepreneurship, no. 3, pp. 154-157 [in Ukrainian].

12. Tomareva V.V. Dysproportsii sotsialnoekonomichnoho rozvytku rehioniv Ukrainy ta shliakhy yikh znyzhennia [Disproportions of socio-economic development of Ukrainian regions and ways to reduce them]. (n.d.). Retrieved from http://archive.nbuv.gov.ua/portal/soc_gum/Dtr_ep/2010_6/files/EC610_23.pdf [in Ukrainian].

13. Uzunov, V. V. (2012). Development of region's innovative infrastructure in Ukraine. Derzhavne upravlinnya: udoskonalennya ta rozvytok, no. 8. available at: Retrieved from http://www.dy.nayka.com.ua/?op=1\&z= 638 [in Ukrainian].

14. Semiv, L. K. (Ed.) (2009). Intelektualno-innovatsiinyi rozvytok rehionu v konteksti yevrointehratsii [Intellectual-innovative development of the region in the context of European integration]. Lviv, Instytut rehionalnykh doslidzhen NAN Ukrainy. 483 p. [in Ukrainian].

15. Pak, V. I. (2016), Increasing the effectiveness of cooperation within the Carpathian Euro region in the sphere of interstate regional management. Efficiency of Public Administration, vol. 3, pp. 167-173 [in Ukrainian].

16. Bezuska, A. Yu. and Lukianykhin, V. O. (2010). Determining the nature of regional governance, its main processes and national development priorities. Ekolohichnyi menedzhment u zahalnii systemi upravlinnia [Environmental management in the general management system], Tezy dopovidei Desiatoi shchorichnoi Vseukrainskoi naukovoi konferentsii [Abstracts of the Tenth Annual AllUkrainian Scientific Conference], April 20-21, pp. 18-19. Sumy [in Ukrainian].

17. Chebotarov V., Glinkowska-Krauze B., Chebotarov Ie. (2019). Menedzhment personalu ekonomichnykh pidrozdiliv pidpryiemstv: obgruntuvannia vykhidnykh innovatsiinykh zasad zabezpechennia [Management of personnel of economic subdivisions of enterprises: justification of initial innovative bases of support]. Economic Herald of the Donbas. № 3(57). pp.156-161 [in Ukrainian]. doi: 10.12958/1817-3772-2019-3(57)-156-161. 
18. Kravtsiv, V. S. (Ed.). (2016). Rozvytok transkordonnoho spivrobitnytstva [Development of cross-border cooperation]. Lviv. 52 p. [in Ukrainian].

19. Dragneva, R. and Wolczuk, K. (2014). The EUUkraine association agreement and the challenges of interregionalism. Review of Central and East European Law, vol. 39, 32 p. doi: 10.1163/15730352-00000019.

20. Krasucka, M. (2010). Rola Euroregionów we współpracy transgranicznej na przykładzie Euroregionu Pradziad. Znaczenie samorządu terytorialnego dla rozwoju regionalnego w Polsce, Niemczech i na Ukrainie, I międzynarodowe forum samorządowe. Pradziad Ekonomiczne Problemy Ustug, nr. 61, Szczecin, Poland, pp. 199-210.

21. Moraliyska, M. (2015). Regional economic cooperation in the Western Balkans and its impact on Bulgaria. Economic Alternatives, issue 1, pp. 100-117. Retrieved from http://www.unwe.bg/uploads/Alternatives/9_Moraliyska.pdf.

22. Miklovda, V. P., Slava, S. S., Sember, S. V. and Papp, V. V. (Eds.). (2013). Stratehichni priorytety ekonomichnoho rozvytku rehionu [Strategic priorities for economic development of the region]. Uzhhorod, Vydavnytstvo FOP Breza A. E. 548 p. [in Ukrainian].

23. Zavadskykh, H. M. (2014). Disproportions of socio-economic development of Ukrainian regions and ways to reduce them. Zbirnyk naukovykh prats Tavriiskoho derzhavnoho ahrotekhnolohichnoho universytetu (ekonomichni nauky), no. 2(26), pp. 76-79 [in Ukrainian].

Цеханович В. Б. Моделі інноваційної інфраструктури в єврорегіонах

Головною метою статті $є$ визначення моделей інноваційних структур в єврорегіонах. Саме на сучасному етапі розвиток єврорегіонального співробітництва в інноваційній сфері та його ефективність визначається можливостями конкретного регіону з урахуванням вибраної моделі інноваційного розвитку, яка формується під впливом ряду факторів: рівень соціально-економічного розвитку регіону, стан розвитку інноваційної інфраструктури, кадровий потенціал в інноваційній сфері, наявність фінансових ресурсів для виробництва та впровадження інновацій, інноваційна політика місцевих органів влади, ступінь державного впливу на інноваційні процеси у регіоні. Взаємозв'язок цих факторів визначає можливості для розвитку єврорегіонального співробітництва у сфері інновацій, а також шляхи подолання перешкод активізації інноваційної діяльності регіонів України. Також у статті розглядаються інноваційні інфраструктури єврорегіонів, що веде до конкурентних переваг регіону і створення різних бізнес-утворень в єврорегіоні.

Ключові слова: єврорегіональне співробітництво, інновації, бізнес-інкубатори, кластери.
Tsekhanovych V. Models of Innovation Infrastructure in the Euroregions

The main purpose of the article is to define models of innovative structures in Euroregions. It is on the modern stage of Development of Euroregional cooperation in the innovative sphere and its efficiency is determined by the capacities of a particular region based on the selected models of innovation development, which is influenced by a number of factors: the level of socio-economic development of the region, the state of development of innovation infrastructure, personnel potential in the sphere of innovation, the availability of financial resources for production and innovation, innovation policy, local authorities, the degree of state influence on the innovation processes in the region. The interrelation of these factors determines the opportunities for the development of Euro-regional cooperation in the field of innovation, as well as ways to overcome the problems that stand in the way of activating the innovation activity of the regions of Ukraine. The article also discusses innovative infrastructure of Euroregions, which leads to competitive advantages of the region and the creation of various business entities in the Euroregion.

Keyword: Euro-regional cooperation, innovations, business incubators, clusters.

Цеханович В. Б. Модели инновационной инфраструктуры в еврорегионах

Главной целью статьи является определение моделей инновационных структур в еврорегионах. Именно на современном этапе развитие еврорегионального сотрудничества в инновационной сфере и его эффективность определяется возможностями конкретного региона с учетом выбранной модели инновационного развития, которая формируется под влиянием ряда факторов: уровень социально-экономического развития региона, состояние развития инновационной инфраструктуры, кадровый потенциал в инновационной сфере, наличие финансовых ресурсов для производства и внедрения инноваций, инновационная политика местных органов власти, степень государственного влияния на инновационные процессы в регионе. Взаимосвязь этих факторов определяет возможности для развития еврорегионального сотрудничества в сфере инноваций, а также пути преодоления препятствий активизации инновационной деятельности регионов Украины. Также в статье рассматриваются инновационные инфраструктуры еврорегионов, что ведет к конкурентным преимуществам региона и созданию различных бизнес образований в еврорегионе.

Ключевые слова: еврорегиональное сотрудничество, инновации, бизнес-инкубаторы, кластеры.

Received by the editors: 11.12.2019 and final form 19.12.2019 